\title{
Suitable small farm reservoir development planning for drought disaster risk management of agricultural land using remote sensing and GIS
}

Wenang Anurogo, Muhammad Zainuddin Lubis, Uuf Brajawidagda, Mir'atul Khusna Mufida, Daniel Sutopo Pamungkas, et al.

Wenang Anurogo, Muhammad Zainuddin Lubis, Uuf Brajawidagda, Mir'atul Khusna Mufida, Daniel Sutopo Pamungkas, Sanjiwana Arjasakusuma, Wikan Jaya Prihantarto, "Suitable small farm reservoir development planning for drought disaster risk management of agricultural land using remote sensing and GIS," Proc. SPIE 11311, Sixth Geoinformation Science Symposium, 113110Q (21 November 2019); doi: 10.1117/12.2548859

SPIE Event: Sixth Geoinformation Science Symposium, 2019, Yogyakarta, Indonesia 


\title{
Suitable Small Farm Reservoir Development Planning for Drought Disaster Risk Management of Agricultural Land Using Remote Sensing and GIS
}

\author{
Wenang Anurogo ${ }^{1 *}$, Muhammad Zainuddin Lubis', Uuf Brajawidagda², Mir'atul Khusna \\ Mufida $^{2}$, Daniel Sutopo Pamungkas ${ }^{3}$, Sanjiwana Arjasakusuma ${ }^{4}$, Wikan Jaya Prihantarto ${ }^{4}$ \\ ${ }^{1}$ Geomatics Engineering, Politeknik Negeri Batam, Batam 29461, Indonesia \\ ${ }^{2}$ Informatics Engineering, Politeknik Negeri Batam, Batam 29461, Indonesia \\ ${ }^{3}$ Electronics Engineering, Politeknik Negeri Batam, Batam 29461, Indonesia \\ ${ }^{4}$ Department of Geographic Information Science, Faculty of Geography Universitas Gadjah Mada, Sekip Utara, 55281 \\ Yogyakarta, Indonesia \\ *Email: wenang@polibatam.ac.id
}

\begin{abstract}
Water is the resource and determinant factor that determines the performance of the agricultural sector, although the role is very strategic, the water management is still far from expected so that the water that should be a farmer's turn turned into a cause of disaster for farmers. Small farm reservoir is built to accommodate excess rainwater during the rainy season. The water collected is then used as a source of supplementary irrigation for the cultivation of high-value economic commodities in the dry season. This research aims to survey, inventory, and study the potential of small farm reservoir development, and to plan potential site locations to be developed into small farm reservoir based on the results of analysis of physical and socio-economic data and drought potential using advanced remote sensing technology in Jombang Regency. Research planning of small farm reservoir location in Jombang Regency is designed in four stages of activity that is data gathering, mapping, and compilation of database, analysis, planning of location, and recommendation of the small farm reservoir location. The results of this research state that the appropriate area built small farm reservoir based on the parameters used are Ngoro, Mojoagung, Kesamben, and Kabuh village.
\end{abstract}

Keywords: Drought, Disaster Risk Management, Remote Sensing, GIS, Small Farm Reservoir

\section{Introduction}

Water is one of the essential natural resources for agricultural production systems (Rendón-von Osten \& DzulCaamal,2017). Water for agriculture is not only related to the aspects of production, but also determines the potential for extension of planting area, planting area, crop intensity, and yield quality (Flávio et al, 2017). Water problems faced by Indonesia are limited water resources and on the other side the increasing demand for water for agriculture, industry, urban and settlement, mining, power generation, tourism, drinking water, health, and others (Sodha et al, 2011). Meanwhile, the regulation on the use of coordinated and holistic water resources to serve the needs of all sectors has not been well socialized to all levels of society. At the same time, efforts to control illegal logging and the conservation and management of forests as a "spring" in the upper reaches have not been well controlled. As a result, water supply for agriculture is decreasing, although irrigation infrastructure is available. With this water scarcity, agricultural development has not given optimal contribution in national food security and self-sufficiency (Marques, 2010).

In quantity, the water problem for agriculture, especially on dry land, is the problem of mismatch of water distribution between the need and supply (Cheremisinoff, 2019) according to time (temporal) and place (spatial). Issues are becoming increasingly complex, complicated and difficult to predict because the water supply depends on the distribution of rainfall throughout the year, which is not evenly distributed even in the 
rainy season (Abbasnia et al, 2019). Therefore, appropriate, inexpensive and applicable technology is needed to regulate the availability of water in order to meet water demand which is increasingly difficult to do in natural ways (DiGiulio \& Jackson, 2016). Technology small farm reservoir is one of the promising choices because the technology is simple, the cost is relatively cheap and can be reached the ability of farmers. Operationally, the small farm reservoir functions to distribute and guarantee the continuity of the availability of water supplies for the needs of plants or livestock in the dry and rainy seasons. To make small farm reservoir, good planning is needed, both location planning, technical planning, and funding planning (budgeting). Development of small farm reservoir locations must meet the physical requirements of land (topography, slope, soil stability, presence of water sources, etc.), as well as the requirements for socio-economic conditions (patterns of agricultural land use, farmers, farmer groups, water user groups, etc.) (Sawunyama et al, 2006).

\section{Methods}

Administratively, this research area is located in Jombang, which is located at $5.2^{\circ}-5.3^{\circ}$ east and $7.2^{\circ}-7.45$ ${ }^{\circ}$ south latitude. Jombang is one of the regencies in East Java Province. The location of research is shown in fiure 1 .

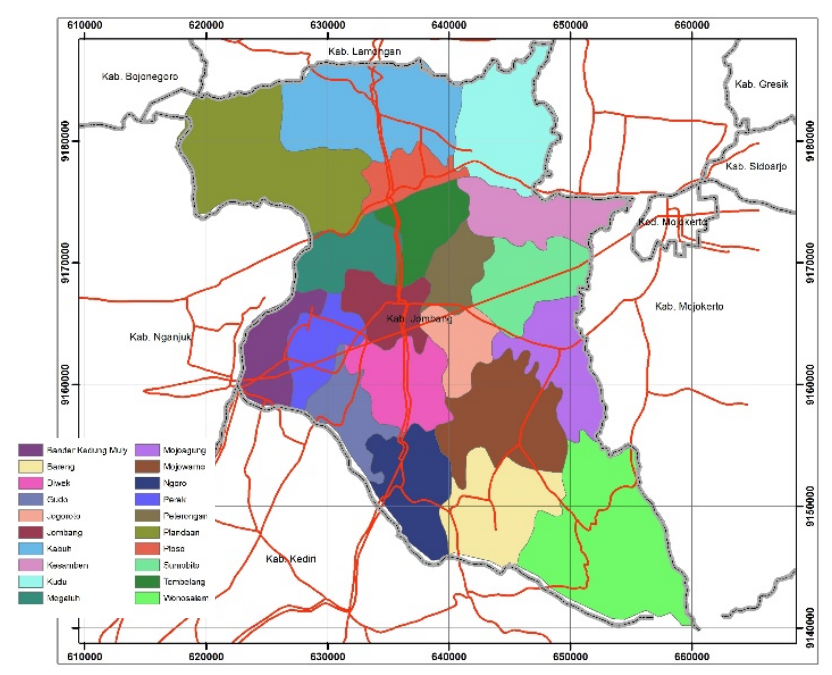

Fig1. Research Area Location

This research uses a combination of remote sensing data, physical appearance data, and socio-economic data of the community. Remote sensing data is used to help extract information on the appearance of parameters used in the research location. The parameters extracted using remote sensing data include land use, soil texture, drainage, slope and potential drought taken from the land surface temperature. Data on the physical appearance of the field are used as additional parameters and are taken when validating field data, while socio-economic data is used to determine the suitability of the location of the small farm reservoir area viewed from the community side. The parameters extracted from remote sensing data are then weighted to determine the classes in each parameter that affect the suitability of the small farm reservoir construction site. All parameter maps are generated (overlay) to produce a map of land units. Furthermore, the land unit map was analyzed by a scoring method to determine the land suitability potential to be used as a small farm reservoir. To determine the suitability of land for the designation of reservoirs, a scoring analysis was conducted. Scoring is done on all components of the land. Drought potential data is extracted using remote sensing data. The data used to extract this drought potential information is Landsat $8 \mathrm{OLI} /$ TIRS. Landsat imagery used to extract drought potential using thermal channels on the image is using channels 10 and 11. After changing the Digital Number value to radians in bands 10 and 11 on the data that has been done radiometric correction, then the spectral value of 
radians is then converted to inner temperature Kelvin unit. Then change the Kelvin temperature to Celsius. The algorithm is shown in formula 1 below (Lubis, et al 2017; Sari et al, 2018; Anderson et al, 2013);

$$
T=\frac{K 2}{\operatorname{In}\left(\frac{K 1}{L \lambda}+1\right)}
$$

$\mathrm{T}=$ Brightness Temperature $(\mathrm{K})$

$\mathrm{L} \lambda=$ TOA spectral radiance $($ watts $/(\mathrm{m} 2 \times \operatorname{srad} \times \mu \mathrm{m})$

$\mathrm{K} 1=$ Band-specific thermal conversion constant (metadata)

$K 2=$ Band-specific thermal conversion constant (metadata)

The LST data is then combined with the moisture data extracted also from Landsat 8 imagery so that the moisture data and LST are combined so that the drought area of the research area is obtained, which will be used as one of the parameters for determining the small farm reservoir location. The humidity algorithm is shown in formula 2 below;

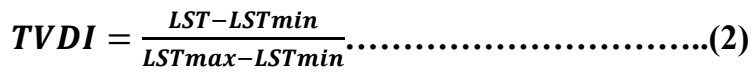

Development of small farm reservoir locations must meet location requirements and social requirements (especially farmers and farmer groups). The area used as the small farm reservoir development site is an area of dry-land /plantation/livestock farming that requires water supply from small farm reservoir as a supply of irrigation water, deep groundwater, not sandy land, there is a source of water that can be accommodated in the form of rainwater, surface flow, and springs or ditches or small rivers, and the upper area has a catchment area or an area that has a water source to be inserted into a reservoir, such as a spring, a small river or a ditch (Maneta et al,2009). While the conditions for farmer groups are willing to provide land for reservoirs and agree on compensation and stated in a statement letter, the selected farmer groups are farmer groups that have been there before, not newly formed farmer groups because of this activity, and are willing to operate, maintain buildings in groups and willing to bear the operational and maintenance costs and stated in the statement (Degefu et al, 2011).

\section{Results and Discussion}

Until the end, several stages of activities and results have been achieved, including thematic maps of land components (base maps, slope maps, land use maps, river network maps), field observations and surveys in the form of soil sample points, and field documentation. The base map is used as the main reference for all thematic maps made. The base map was compiled from a 1:25,000 scale RBI map, containing basic information (roads, administrative boundaries, toponymy, and coordinate systems). The slope map is derived from a contour map found on a 1: 25,000 scale RBI map. Land use map is obtained from the interpretation of satellite imagery. The river network map derived from the RBI map is supported by image interpretation. Field observations and surveys are carried out by all surveyors. The activities carried out in the observation activities are mainly the collection of soil physical data, terrain topographic orientation, topsoil sampling, and field documentation. In addition, in the field observation activities also carried out secondary data collection. The location of the observation in the field observation is endeavoured to be able to cover all sub-districts in Jombang, but it is prioritized in areas that are experiencing water difficulties for agricultural purposes. At each observation site that is indeed potential for the development of reservoirs, soil samples are taken at least 3 sample points. The topsoil samples will then be analysed in a soil test laboratory. Soil observations in the field include land morphology, namely altitude, slope, and land use, and soil morphology, such as the thickness of the top layer, 
soil structure, and soil texture. As much as possible in the field observation activities carried out interviews with farmers to gather socio-economic information and potential social impacts on reservoir development.

The first information extraction is done is making land-use data he image classification process is carried out through the training set by making a vector delineation that surrounds the intended object to be considered representative and made into a class. Delineation is done by providing numerical identity (ID) based on the gray number. The result of delineation is in the form of a set of limiting polygons against a selected set of features. After the vector delineation process is considered to be sufficiently representative, the signature process is continued. The results of this process are the price of the number of pixels in a training set, the maximum price, the minimum price, and the average price of a digital number (digital number grayscale) and the standard deviation price expressed in percent.

In the process of image classification, the Maximum Likelihood technique is used. The results of the classified image are land use consisting of nine types of use. Furthermore, the interpretation of the objects for each class is carried out according to the characteristics and reflectance graphs in the signature comparison module. Based on the results of these interpretations, ground truth and field verification are then conducted to obtain information that is appropriate to the field conditions. Ground truth is the process of matching the results of image classification that has been interpreted with the state of land cover in the field, while field verification is a stage to obtain certainty of objects that are classified based on secondary data or description/observations. Land use data in Jombang is shown in Figure 2.

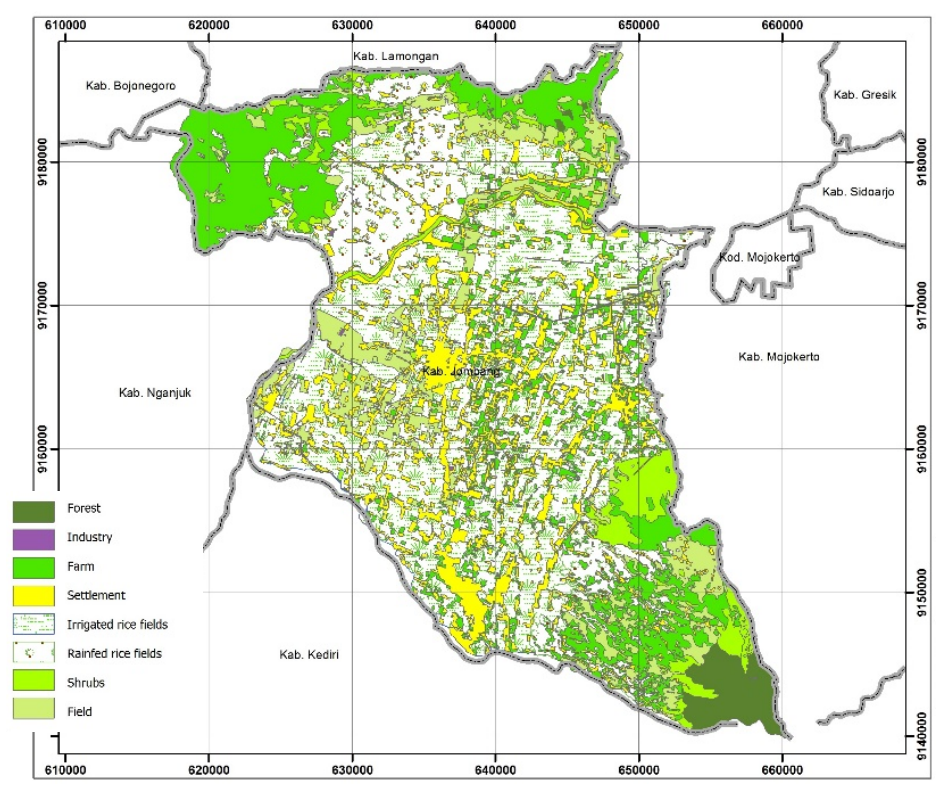

Fig. 2 Map of Land-use in research area

Drought potential data used as one of the parameters extracted using Landsat data. Drought parameters are obtained using LST and NDWI parameters by using remote sensing image data The wetness index shows the degree of wetness of an area recorded by the image. Thus, NDWI and NDVI values are directly proportional, the denser the density of vegetation in an area, the higher the NDWI value recorded. In relation to drought, the lower the NDWI value, the more vulnerable the area is to drought, on the contrary, the higher the NDWI value, the lower the vulnerability to drought. Wetness index processing using the NDWI algorithm uses NIR bands and SWIR bands. The soil surface temperature is used as a parameter of the drought of this plantation area because the increased surface temperature causes an increase in evapotranspiration so that the availability of 
water for plants will decrease. In relation to drought, the higher the surface temperature of the soil, the higher the susceptibility to drought, and vice versa the lower the surface temperature of the soil, the lower the vulnerability to drought. The Temperature Vegetation Dryness Index (TVDI) is the last parameter used to look for potential drought. TVDI is a drought index determined based on empirical parameters of the relationship between the Normalized Difference Vegetation Index (NDVI) and the Land Surface Temperature (LST). The index is associated with soil moisture and is obtained only based on input from remote sensing satellite information. In a particular land, NDVI values will generally increase along with LST decreases. This relates to the ability of vegetation to regulate its temperature through latent heat transfer, i.e. heat transfer through evapotranspiration. Drought potential data in the study area is shown in Figure 3.

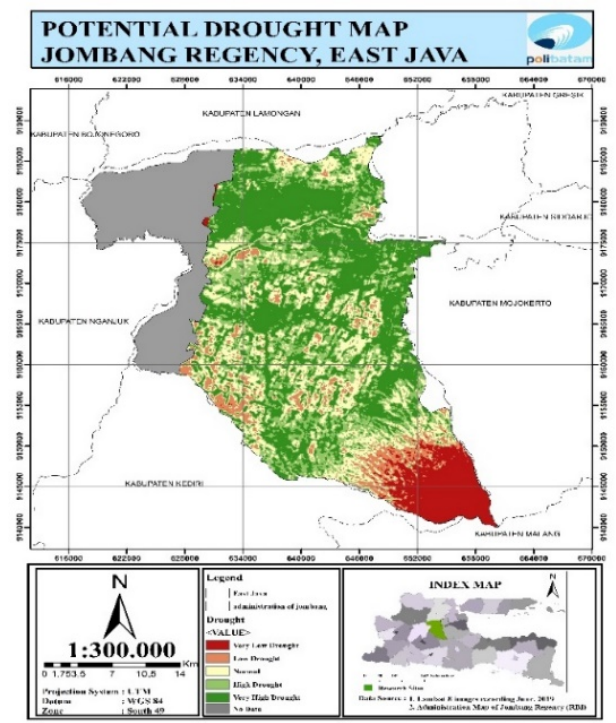

Fig.3 Drought Potential Map

All parameters that have been made, then given a score on each class in each parameter. Then the total score is given for the suitability of the reservoir development which is then combined with physical data from field observations and socio-economic data. Based on the final data generated, a suitable potential location for building reservoirs is shown in Figure 4.

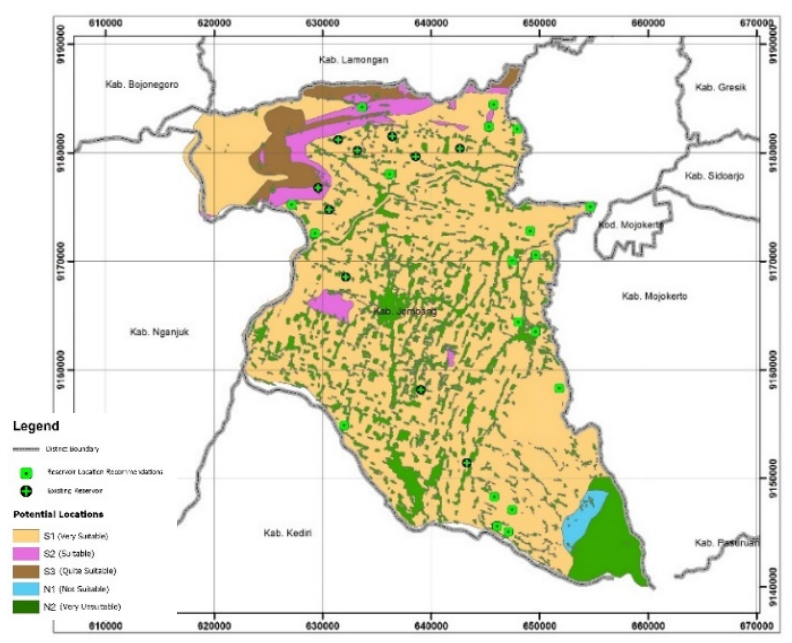

Fig. 4 Map of suitability of potential reservoir development locations 


\section{Conclusions}

Based on the overlapping results of all parameters used to find the suitability of potential reservoir development in the study area, the most suitable and most potential locations for reservoir development are Ngoro, Mojoagung, Kesamben, and Kabuh sub-districts.

\section{References}

[1] Rendón-von Osten, J., \& Dzul-Caamal, R. (2017). Glyphosate residues in groundwater, drinking water and urine of subsistence farmers from intensive agriculture localities: a survey in Hopelchén, Campeche, Mexico. International journal of environmental research and public health, 14(6), 595.

[2] Flávio, H. M., Ferreira, P., Formigo, N., \& Svendsen, J. C. (2017). Reconciling agriculture and stream restoration in Europe: A review relating to the EU Water Framework Directive. Science of the Total Environment, 596, 378-395.

[3] Sodha, S. V., Menon, M., Trivedi, K., Ati, A., Figueroa, M. E., Ainslie, R., ... \& Quick, R. (2011). Microbiologic effectiveness of boiling and safe water storage in South Sulawesi, Indonesia. Journal of water and health, 9(3), 577-585.

[4] Marques, R. C. (2010). Regulation of water and wastewater services. IWA publishing.

[5] Lubis, M. Z., Taki, H. M., Anurogo, W., Pamungkas, D. S., Wicaksono, P., \& Aprilliyanti, T. (2017, December). Mapping the distribution of potential land drought in Batam Island using the integration of remote sensing and geographic information systems (GIS). In IOP Conference Series: Earth and Environmental Science (Vol. 98, No. 1, p. 012012).

[6] Sari, R., Anurogo, W., \& Lubis, M. Z. (2018). Pemetaan Sebaran Suhu Penggunaan Lahan Menggunakan Citra Landsat 8 di Pulau Batam. Jurnal Integrasi, 10(1), 32-39.

[7] Cheremisinoff, P. N. (2019). Handbook of water and wastewater treatment technology. Routledge.

[8] Abbasnia, A., Yousefi, N., Mahvi, A. H., Nabizadeh, R., Radfard, M., Yousefi, M., \& Alimohammadi, M. (2019). Evaluation of groundwater quality using water quality index and its suitability for assessing water for drinking and irrigation purposes: Case study of Sistan and Baluchistan province (Iran). Human and Ecological Risk Assessment: An International Journal, 25(4), 988-1005.

[9] DiGiulio, D. C., \& Jackson, R. B. (2016). Impact to underground sources of drinking water and domestic wells from production well stimulation and completion practices in the Pavillion, Wyoming, field. Environmental science \& technology, 50(8), 4524-4536.

[10] Sawunyama, T. E. N. D. A. I., Senzanje, A., \& Mhizha, A. (2006). Estimation of small reservoir storage capacities in Limpopo River Basin using geographical information systems (GIS) and remotely sensed surface areas: Case of Mzingwane catchment. Physics and Chemistry of the Earth, Parts A/B/C, 31(15-16), 935-943.

[11] Anderson, M. C., Hain, C., Otkin, J., Zhan, X., Mo, K., Svoboda, M., ... \& Pimstein, A. (2013). An intercomparison of drought indicators based on thermal remote sensing and NLDAS-2 simulations with US Drought Monitor classifications. Journal of Hydrometeorology, 14(4), 1035-1056.

[12] Degefu, F., Mengistu, S., \& Schagerl, M. (2011). Influence of fish cage farming on water quality and plankton in fish ponds: A case study in the Rift Valley and North Shoa reservoirs, Ethiopia. Aquaculture, $316(1-4), 129-135$. 
[13] Maneta, M. P., Torres, M. D. O., Wallender, W. W., Vosti, S., Howitt, R., Rodrigues, L., ... \& Panday, S. (2009). A spatially distributed hydroeconomic model to assess the effects of drought on land use, farm profits, and agricultural employment. Water Resources Research, 45(11). 